\title{
Identifying and Structuring Values to Guide the Choice of Sustainability Indicators for Tourism Development
}

\section{Marta Chávez-Cortés ${ }^{1, *}$ and José Alberto Alcántara Maya ${ }^{2}$}

1 Laboratorio de SIG aplicados a la Planeación Ambiental, Departamento El Hombre y su Ambiente, Universidad Autónoma Metropolitana-Xochimilco, Calz. del Hueso 1100, Col. Villa Quietud, C.P. 04960, Coyoacán, D.F., México

2 Departamento Planeación y Seguimiento de Sistemas, Apoyos y Servicios a la Comercialización Agropecuaria (ASERCA), José María Ibarrarán 84, Col. San José Insurgentes, C.P. 03900, Benito Juárez, D.F., México; E-Mail: kennett01 @ hotmail.com

* Author to whom correspondence should be addressed; E-Mail: ccmm1320@ correo.xoc.uam.mx; Tel.: +1-55-5483-7225; Fax: +1-55-5723-5469.

Received: 17 August 2010; in revised form: 7 September 2010 / Accepted: 8 September 2010 / Published: 17 September 2010

\begin{abstract}
In Mexico, the National Trust for Tourism Promotion (FONATUR) needs to lead development of Integrally Planned Tourist Centers (IPC) towards sustainability. As the development of these IPCs leads to changes in local communities and their environment, it is necessary to define how to establish a path towards sustainability and how to measure progress towards that goal. The objective of this study is to contribute toward identifying the main stakeholder's values, defining sustainability indicators at a local level, and to discuss their adequacy in the context of tourism development. The study was performed in a Mexican community facing its probable inclusion in tourism development and special attention was given to the values of stakeholders in defining which objectives to monitor. Using Value-Focused Thinking as a framework, a series of interviews were analyzed and the opinions were organized in a tree of values, encompassing environmental, economic, social and political/institutional aspects. A set of indicators associated with these objectives was subsequently proposed. This information may serve as a guide to design and monitor plans that are more appealing from a sustainability perspective and as an aid in the identification of future information needs.
\end{abstract}


Keywords: indicators; value-focused thinking; sustainability; touristic developments

\section{Introduction}

Tourism has long been recognized as one of the major revenue generators for world economies [1], employing more than 235 million people worldwide and generating some 9.2\% of global GDP [2]. Indeed, this seems to be the case for Mexico, as indicated by the 46,900,000 foreign visitors leaving the country earnings of 5,726 million dollars just during the first half of 2008, in addition to private investments totaling 316 million dollars. The additional fact that Mexico occupies the first place in luxury liners' arrivals in the world [3,4] sums up the relevance of tourism for the Mexican economy. The huge importance of tourism related revenues for the world's economy, particularly for developing countries, continuously dictates the creation of policies that support its development worldwide [5]. However, despite its positive impact on the economy, this activity can also have negative effects from the environmental, social and cultural viewpoints $[1,5,6]$. Tourism is thus not just an opportunity, but a challenge as well, for the regions where it is developed.

This dual nature of tourism led to the search for alternative tourism planning, management and development options. As a result, after the Special Assembly of the United Nations, known as "Rio + 5" - in 1997-the tourism sector adopted the objective of sustainable development [7]. The World Tourism Organization (WTO) defines sustainable tourism as that which "meets the needs of tourists and host regions, while at the same time it protects and improves opportunities for the future. It focuses on the management of all the resources in such a way that all economic, social, and aesthetic needs are met, while cultural integrity, key ecological processes, biodiversity, and life support systems, are respected" [8]. However, a widely accepted definition of this concept does not exist [7,9,10]. What exists is a common understanding that it is necessary to develop tourism policies that guarantee the protection of natural, social and cultural resources and ensure these resources can meet current and future residents and tourist needs [11]. During the process of designing and implementing such policies, indicators of sustainable tourism can help put into effect this concept and introduce it in the policy monitoring arena, in order to define more suitable policies [12]. This is why varied efforts have been made during the last decades to develop sustainability indicators for this and other sectors. WTO, for example, has been undertaking work in this field since 1992 [8,13]. In developing sustainability indicators, two mainstream approaches have been identified [14]: a top-down approach guided by experts and a bottom-up approach based on the communities. The first is epistemologically rooted in scientific reductionism and specifically uses quantitative indicators. While this approach acknowledges the need to quantify the complexities of dynamical systems, it does not necessarily emphasize the complex variety of perspectives for the resource user. Pressure-State-Response (PSR, DSR and DPSIR) [15], Well Being Assessment [16] and Orientation Theory [17] are examples of methodologies that pertain to this framework. The second approach is based on participatory philosophy from the bottom-up and finds support in social science. Research along this line emphasizes the importance of understanding local context in order to establish objectives and priorities, arguing that sustainability must be a continued process of learning for both the community and the researcher [18]. Examples of 
this methodological framework applied at the local scale are Soft System Analysis [19], Sustainable Livelihoods Analysis [18], The Natural Step [20] and Value-Focused Thinking [21]. Those who propose this approach claim that consultation with local stakeholders helps discover new perspectives about the local situation and ensures that all values - what we care about - of different actors are well known and considered in defining the way of monitoring progress towards sustainability [12,22]. At first sight, these two approaches seem different from their very foundations, but there is an increasing awareness and academic debate on the need to capture the best from both knowledge pools. However, there still persists a lack of agreement about the best way to achieve this [18].

On the other hand, progressive thinking in both sustainability science and sustainable tourism development does not assume that issues are similar from place to place [23]. Reed and Doughill [24] advocate that local scale sustainability assessments tend to be more appropriate and relevant than those on a larger scale. It has also been recognized that there needs to be a new emphasis on both-local context and multiple expertise-incorporating the knowledge of the community and the experts [25], as has been called for already in the sustainable development and sustainable tourism fields.

Indicators can provide crucial guidance for decision making in a variety of ways. They can translate physical and social science knowledge into manageable units of information that can facilitate the decision making process. They can help measure and calibrate progress towards sustainable development goals. They can provide an early warning, sounding the alarm in time to prevent economic, social and environmental damage [26]. They are also important tools to communicate ideas, thoughts and values because, as one authority said "We measure what we value, and value what we measure" [27]. Thus, in any decision making process relevant to sustainability, elicitation of values, and their clarification through an explicit statement of specific objectives, is a key step to develop strategic approaches [28]. A set of objectives used to evaluate alternatives and their progress through time is the foundation on which every sustainability-related analysis is built. In many situations, the main disputes about an analysis or its implications have their origin in a set of objectives which do not encompass all the areas of interest for the stakeholders [29]. Consequently, such an analysis will be of limited use, either in fulfilling its evaluation objective or in fostering communication among interested parties, because it only offers a restricted insight of the actual concerns involved. This also leads to very weak support on any negotiation or compromise that might arise among the stakeholders [30] and, ultimately, to the lack of support for any initiative to move towards sustainability [31].

Tourism activity in Mexico, like in many other countries, has grown substantially over the last decades [4,6,32]. Consequently, if this economic activity is to be developed without negatively influencing the environment and the local society, it is a must to devise strategies that place this activity on a path towards sustainability and keep it on that course. This need has been widely recognized in international resolutions (Lanzarote Charter, 1995; Lisbon Strategy, 2000), scientific studies [33-35] and practical terms. For instance, in the case of tourism projects seeking financing from the Interamerican Development Bank (BID) or applying for a quality certification, it is a requirement to make explicit their commitment to sustainability and demonstrate its effectiveness [36,37]. Moreover, this tendency has already been manifested as a change of vision in tourism planning and development at national tourism institutions like the Spanish Tourism Institute (TURESPAÑA), Direction du Tourisme in France, Britain's National Tourism Agency, Office of Travel and Tourism Industries (OTTI) in the U.S. and the National Trust for Tourism Promotion (FONATUR) in México. 
Proof of this change is the discourse of programs and projects linked to the planning and operation of tourism in Mexico, which now includes the vision and dimensions of sustainable tourism as part of its objectives and actions. Some examples are the project Agenda 21 for Mexican Tourism, the Sector Tourism Program 2007-2012, as well as the partial and main plans for the Integrally Planned Tourism Centers (IPC) [32].

IPCs make up the main Mexican strategy to foster tourism, framed within a sustainability context and the concern for the integration of local communities to this activity. FONATUR is in charge of planning and development of IPCs, while their construction is financed with the support of BID. Five such centers have been in development since 1993: Cancún, Loreto, Ixtapa, Los Cabos and 10 years later, Bahías de Huatulco. However, as the development of these IPCs leads inevitably to changes in local communities and their environment, it is necessary to define how to measure progress towards a sustainable path. The objective of this study is to make a contribution in identifying stakeholder's values, using them as a base to define sustainability indicators at the local level and to discuss their adequacy in a tourism development context. The study was performed in a Mexican community which faces its probable inclusion in tourism development.

This research was based on stakeholder interviews, which were analyzed and structured according to the principles of the value-focused thinking approach [21]. This is an alternative approach for decision making. The usual method for decision making involves selecting a solution from an available set of options ranked from the best to the worst [21]. Behind the selection of a specific option is always the aim of gaining specific benefits and avoiding undesirable consequences. Thus, options are the means to achieve more fundamental values. In contrast, value-focused thinking begins with defining the best possible option, through the elicitation of one's objectives (values), and works toward making this option a reality.

In the context of sustainability indicators, rather than starting with a set of previously identified indicators and evaluating which are preferred, value-focused thinking starts with the identification of the fundamental values underlying the decision context and works from them towards the proposal of a set of indicators tailored to what is considered important. In our opinion, sustainability indicators will thus be more accurately rooted in the stakeholder's values.

Among the variety of advantages that can be gained by thinking about values, are: helping to discover hidden objectives and leading to more productive elicitation of information. It can also improve communication among stakeholders, ease the participation or involvement of the interested parties, and aid in the coordination of interconnected decisions. The major benefit of this methodological approach comes from the guidance it offers in creating better alternatives to a decision problem [38]. Value-focused thinking has been applied to several types of decisions ranging from the operation of service organizations [39] to natural resource conflicts management [38], including tourism management [40] and tourism planning [41]. The application of this approach in the manner described here has only been reported in one case study, that of Gregory and Kenney [42], in the context of creating "policy alternatives". 


\section{Area of Study}

Copalita is a location in the municipality of Santa María Huatulco, two kilometers from the municipal capital. It stretches along the Copalita River, which is in turn the municipal limit between Santa María Huatulco and San Miguel del Puerto. The area is part of a polygon owned by FONATUR, hosting the Bahías de Huatulco tourist development. The community of Copalita is constituted by 255 inhabitants distributed in 58 families. The area has an important environmental wealth composed of two main types of vegetation: low dry forest and riparian vegetation, the first of which is in an almost pristine state [43]. Four hundred and eleven animal species have been registered, predominantly birds. There are, besides, forty three endangered, threatened and rare species, some of them under special protection [44]. These characteristics confer an excellent potential to the area for touristic use.

To date, tourism development in the area has been modest, centering its activities on visits to the orchards, to a Botanical Zoological Park known as the Botazoo and on rafting activities in the river. However, it is expected that its relevance as a site of touristic interest will increase, especially in the areas of tourism in contact with nature and cultural tourism.

The main socio-economic problems of the site are land use conflicts, derived from irregular settlements and a lack of jobs. While economic activity is centered on agriculture, it should be noted that its relevance as an environmental impact factor is rather limited. This is because the lands, after being expropriated, became the property of FONATUR and this institution imposes limits on agricultural land use. Contrastingly, the possibilities for tourism are very interesting due to the natural beauty of the area, which includes, besides lush vegetation, exceptional views of the sea, a wealth of species and the archaeological sites it encloses.

\section{Materials and Methods}

The application of the value-focused thinking approach to the current case followed these steps: (1) recognize a decision problem; (2) select the stakeholders; (3) identify and specify values; (4) propose a set of sustainability indicators. These steps are described next.

\subsection{The Decision Problem}

In the context outlined in the previous section, the question FONATUR seeks to answer can be phrased thus: how can progress towards sustainability be measured in a community facing the challenge of an incoming tourism development? Deciding how leads to further questions about which are the relevant values influencing this decision and the ways to measure them.

\subsection{Selection of Stakeholders}

The most obvious way to identify a complete range of relevant values influencing a decision is to ask individuals with diverse interests what they think is important and required to make that decision [29]. However, one of the most difficult aspects to deal with is the choice of who should be involved, since there is always the risk of leaving one of the parties out.

Stakeholders were selected for this research based on recommendations from the World Tourism Organization, which include five categories: communities, public sector, private sector, 
non-governmental organizations and tourists [45]. From these categories, the private sector and the tourists were not considered, since the site has not developed yet in these directions (service providers). Nevertheless, taking into account considerations made by Jennings [46], a new category was included: the academic sector, because of its role as the generator and applier of knowledge that guides development policies. The list of those interviewed is shown in Table 1.

It is important to emphasize that selecting participants also implies a balance of several factors, such as the length and cost of the interviewing period, the availability of participants and their contribution to the legitimacy of the process [29]. In this case, only two weeks were available for the interviews, most people from the community preferred to be interviewed at the weekend while others declined to participate arguing a lack of time. Collectively, these factors restricted the number of interviews.

Table 1. List of interviewees.

\begin{tabular}{|l|l|c|l|}
\hline \multicolumn{1}{|c|}{ Entity } & \multicolumn{1}{|c|}{ Name } & $\begin{array}{c}\text { \# of } \\
\text { interviews }\end{array}$ & \multicolumn{1}{c|}{ Position/Task } \\
\hline \multirow{3}{*}{ FONATUR México } & Arq. Alejandro Polo & 1 & Technical planning aspects \\
\cline { 2 - 4 } & Lic. Patricia Orozco & 1 & The Community's Development Office. \\
\cline { 2 - 5 } & Biól. Marco Antonio García & 1 & Environmental Affairs \\
\hline \multirow{2}{*}{ FONATUR Huatulco } & Ing. Alfredo Cuevas & 1 & Head of Planning Department \\
\cline { 2 - 5 } Municipal Government & Lic. Víctor René Solís Zurita & 1 & Community's Development Area \\
\hline GAIA NGO & Sr. Aarón Vázquez Chávez & 1 & $\begin{array}{l}\text { Ecology Regent, Santa Ma. Huatulco } \\
\text { Municipality }\end{array}$ \\
\hline Copalita Community & Biól. Pavel Palacios Chávez & 1 & NGO's Regional Coordinator \\
\hline \multirow{2}{*}{ Academic Community } & General Public & 30 & Community residents \\
\cline { 2 - 5 } & $\begin{array}{l}\text { M. en SIG. Gilberto Binqüist } \\
\text { Cervantes }\end{array}$ & 1 & $\begin{array}{l}\text { Professor. UAM-Xochimilco. Environmental } \\
\text { Planning }\end{array}$ \\
\hline
\end{tabular}

Considering that planning for sustainability should be flexible to allow improvements [47-49], information gathered from this study can be seen as a first approximation towards a more complete vision of the most important issues worth considering when sustainability is included in the context of the site. In this perspective, it is not reasonable to look for once-and-for-all decisions, but for a progressive commitment towards the articulation of context-dependent improvements. That is why the construction of a first package of indicators is considered as a step in the planning process, as it can be changed as new information becomes available, unexpected events unfold or the planners obtain further insights $[49,50]$.

\subsection{Identification of Stakeholders' Values}

In a sustainability context, as in many others, the first requirement in the construction of a decision making tool, is the identification of a set of appropriate objectives or goals, in order to evaluate later on the degree to which they have been attained [51]. In this respect, there is general agreement that these objectives or goals are influenced, as much by the values and perspectives of the persons involved in the problem, as they are by those of the decision makers. For this reason, literature on the subject 
suggests that related research should be approached in a way that is sensitive to the way people perceive the world [52].

There are several methods to obtain information about people's perceptions. One of them consists of workgroups of key stakeholders, where qualified participants - those that deal with a situation on a daily basis-must necessarily arrive at a consensus over the subject in dispute [46]. Another is the expert's judgment, in which the planner looks for the values and preferences of stakeholders through interviews, making a synthesis of their contributions [53]. The application of one method over the other depends on a series of considerations such as: availability of the participants, number of people involved and resources — economic and human — needed to implement them.

Considering these variables, the experts' judgment method was used in this research, supported by personal interviews of a semi-structured nature [52,54]. This type of interview is the most common in qualitative work, where there is an interest in listening to what the informant has to say about the subjects and areas chosen by the academic, which is the case with this research.

Under this approach, a total of 39 interviews were conducted, following Arksey and Knight's suggestions [52]. The subjects setting the course of the interviews were:

1. For the community. What people appreciate about the site, how they would like to live, their expectations about their way of living, the problems recognized within the community, and the convenience of developing tourism.

2. For FONATUR officials. Objectives pursued by the project, why are they important (to distinguish goals from the ways to attain them).

3. For officials of the Municipal Government. The problems of the community to improve their life conditions, the interest of the local government in developing tourism, the municipal government's capability to protect the environment at the site and its coordination with FONATUR.

4. For the NGO. The problems of the community to improve their life conditions, actions undertaken in the community to foster sustainability.

5. For the academic sector. The directions that should be followed to foster ecological sustainability at the site.

\subsection{Structuring and Combination of Different Values}

A hierarchy is a natural way to structure a set of objectives or values [55,56]. Here we used the taxonomic sense of the concept, which consists of a classification of objects from the general to the specific, where a lower level object is a member of a higher class. There was no attempt to set priorities among objectives, as we wanted to derive a set of structured objectives that reflected all factors that should be important to FONATUR in making a decision about tourist development regarding sustainability.

To determine the main objectives of the stakeholders' hierarchies the content of the interviews was examined using phrases as units of analysis. The analysis consisted of exploring the answers given by those interviewed, identifying the phrases that reflected their concerns, expectations, worries or interests, about the basic dimensions of sustainability (environment, economy and society), in the face of the integration of Copalita to touristic activities. A set of standardized phrases was later used to 
encode them. Each phrase was written down and grouped in a column with others that were similar. The columns were aggregated into categories developed by judging which idea best communicated the set of phrases and could, at the same time, play the role of main objective. This categorization went from coarse to fine analysis when it was necessary to specify concepts [21,57]. It is because of this that, although the set of objectives was initially arranged according to the three dimensions: environmental, economic and social, during the process it was necessary to add others that allowed a more precise classification of some of the ideas produced by the different participants.

The combination of objectives was made using the authors' judgment. The fundamental objectives from individual hierarchies were listed, identifying overlapping categories or natural relationships among hierarchies, in order to condense the list and with it, the main objectives were determined.

After the initial set of objectives was selected, the second level objectives of each stakeholder's hierarchy were placed under their main associated objectives. Objective aggregation was repeated at this level according to any natural relation that was identified. The process went on through successive levels. When it was completed, each objective from every hierarchy was verified to ensure its inclusion, either explicit or implicit, in the combined hierarchy of objectives [21].

\subsection{Choosing the Sustainability Indicators}

After the objectives of all interviewed subjects were integrated, they were the starting point to choose indicators based on a revision of specialized literature [26]. Some indicators were also identified from a direct analysis of the interviews.

\section{Results}

The application of the value-focused thinking approach to our case study is summed up by Table 2 and Figure 1. Table 2 describes a hierarchy of objectives from all the stakeholders that were interviewed, allowing the identification of their differences and similarities. Figure 1 illustrates an integration of the different points of view, organized according to the dimensions of sustainability. The main results of the value-focused interview analysis are addressed next.

\subsection{Structure of Values for the Community}

For this group, two general categories of objectives were identified that are of special interest. The Health issue voices a concern for the insufficient medical services at the site, due to the risk that entails, for the inhabitants, not having accessible and timely medical attention. The Education subject accounts for the lack of public schools, since, although the basic demands of elementary and middle school are being met, there are no alternatives for children younger than six years. This objective could reflect a change of vision about children's education, in which the importance of early education is recognized as a means to develop children intellectually and emotionally. It could also be interpreted, however, that mothers with little children need a safe place to leave the kids at while they work. As stated by Allen and Sachs [58], this is an important point to consider from a gender and sustainability perspective, if equal relations between men and women are to be established, relative to economic, social and natural resources. 
Table 2. Overall view of stakeholder's values considering future tourism development in Copalita.

\begin{tabular}{|c|c|c|c|c|c|c|c|c|c|}
\hline Dimension & \multicolumn{3}{|c|}{ Community } & FONATUR & \multicolumn{2}{|c|}{ Municipal Government } & GAIA NGO & \multicolumn{2}{|c|}{ Academic Sector } \\
\hline \multirow{6}{*}{$\begin{array}{l}\text { Environ- } \\
\text { mental }\end{array}$} & \multirow{5}{*}{$\begin{array}{l}\text { Conserve } \\
\text { sources of } \\
\text { environmental } \\
\text { goods and } \\
\text { services }\end{array}$} & \multicolumn{2}{|c|}{$\begin{array}{l}\text { Restrict extraction of material } \\
\text { from Copalita River }\end{array}$} & \multirow{3}{*}{$\begin{array}{l}\text { Stretch life-cycle of resources supporting } \\
\text { tourism }\end{array}$} & \multirow{2}{*}{$\begin{array}{l}\text { Reduce land } \\
\text { use change } \\
\text { effects }\end{array}$} & $\begin{array}{l}\text { Stop } \\
\text { deforestation }\end{array}$ & \multirow[b]{2}{*}{ Conserve biological diversity } & \multirow{2}{*}{$\begin{array}{l}\text { Conserve } \\
\text { environmental } \\
\text { goods and } \\
\text { services } \\
\text { (soil, water, } \\
\text { biodiversity) }\end{array}$} & $\begin{array}{l}\text { Conserve } \\
\text { ecologically } \\
\text { sensitive } \\
\text { areas }\end{array}$ \\
\hline & & \multirow{3}{*}{$\begin{array}{l}\text { Prevent and } \\
\text { control } \\
\text { deforestation }\end{array}$} & $\begin{array}{l}\text { Control } \\
\text { urban } \\
\text { development }\end{array}$ & & & $\begin{array}{l}\text { Prevent } \\
\text { constructions in } \\
\text { expropriated } \\
\text { areas }\end{array}$ & & & \begin{tabular}{|l} 
Preserve \\
gallery \\
and low \\
deciduous \\
forest
\end{tabular} \\
\hline & & & $\begin{array}{l}\text { Stop } \\
\text { excessive } \\
\text { logging }\end{array}$ & & \multirow[t]{3}{*}{$\begin{array}{l}\text { Prevent and } \\
\text { control } \\
\text { pollution }\end{array}$} & $\begin{array}{l}\text { Proper solid } \\
\text { waste disposal }\end{array}$ & \multirow[t]{2}{*}{ Control deforestation } & $\begin{array}{l}\text { Minimize } \\
\text { environmental } \\
\text { impact from } \\
\text { tourism }\end{array}$ & $\begin{array}{l}\text { Reorient } \\
\text { land use } \\
\text { from } \\
\text { touristic } \\
\text { reserve and } \\
\text { tourist resort } \\
\text { towards a } \\
\text { low impact } \\
\text { use }\end{array}$ \\
\hline & & & $\begin{array}{l}\text { Control } \\
\text { agricultural } \\
\text { activities } \\
\end{array}$ & \multirow{3}{*}{$\begin{array}{l}\text { Preserve and reasonably use natural } \\
\text { resources }\end{array}$} & & $\begin{array}{l}\text { Treat municipal } \\
\text { waste waters }\end{array}$ & & & \\
\hline & & $\begin{array}{l}\text { Conserve natu } \\
\text { areas surrounc }\end{array}$ & $\begin{array}{l}\text { protected } \\
\text { g community }\end{array}$ & & & $\begin{array}{l}\text { Control air } \\
\text { pollution }\end{array}$ & \multirow{2}{*}{$\begin{array}{l}\text { Minimize environmental } \\
\text { impact from development } \\
\text { projects }\end{array}$} & & \\
\hline & $\begin{array}{l}\text { Prevent and } \\
\text { control } \\
\text { pollution }\end{array}$ & \multicolumn{2}{|c|}{$\begin{array}{l}\text { Adequate management of } \\
\text { waste disposal }\end{array}$} & & \multicolumn{2}{|c|}{ Conserve biological diversity } & & & \\
\hline
\end{tabular}


Table 2. Cont.




Table 2. Cont

\begin{tabular}{|c|c|c|c|c|c|c|c|}
\hline Education & \multicolumn{2}{|c|}{$\begin{array}{l}\text { Satisfy elementary schooling (pre-school) } \\
\text { needs }\end{array}$} & \multicolumn{2}{|c|}{$\begin{array}{l}\text { Create consciousness of natural resources } \\
\text { protection among the population }\end{array}$} & $\begin{array}{l}\text { Create consciousness among the } \\
\text { population about environmental } \\
\text { protection }\end{array}$ & $\begin{array}{l}\text { Create consciousness among } \\
\text { the population about } \\
\text { environmental protection }\end{array}$ & $\begin{array}{l}\text { Create consciousness among } \\
\text { the population about } \\
\text { environmental protection }\end{array}$ \\
\hline Health & \multicolumn{2}{|c|}{ Improve public health services } & & & & & \\
\hline \multirow{2}{*}{$\begin{array}{l}\text { Political } \\
\text { /institutional }\end{array}$} & $\begin{array}{l}\text { Improve } \\
\text { institutional }\end{array}$ & $\begin{array}{l}\text { Fulfill the compensation } \\
\text { agreements }\end{array}$ & \multirow{2}{*}{$\begin{array}{l}\text { Halt } \\
\text { social } \\
\text { pressure }\end{array}$} & \multirow{2}{*}{$\begin{array}{l}\text { Make use of spaces prone to } \\
\text { irregular settlements }\end{array}$} & & & \\
\hline & $\begin{array}{l}\text { response from } \\
\text { FONATUR }\end{array}$ & Finish the relocation process & & & & & \\
\hline
\end{tabular}

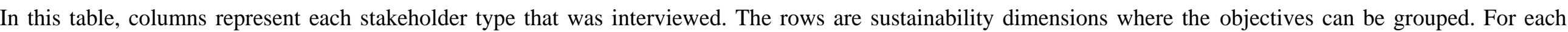


many parts as is necessary, building a hierarchy with three levels of depth at most.

Under the Politics dimension, the answers FONATUR can give to the compensation and relocation agreements were deemed very important. It should be noted that the failure in honoring these agreements has been mainly due to the recent economic insolvency of FONATUR, which has led it to lag in the fulfillment of its obligations. As a consequence of this, villagers have tried to take advantage, promoting the invasion of lands and facilities as a means of exerting pressure. Additionally, they have incremented their compensation and relocation demands; it is in this way that now, not only the original land owners demand a relocated piece of land, but their children as well. This places FONATUR in a dilemma, as land available for human settlements is scarce and more areas would have to be opened for urban use to satisfy such a demand, bringing about loss of natural capital, as well as high economic and political costs for the institution. It is clear that in order to walk on a path towards sustainability, the institution will have to seek new agreements with the community, taking action to break this vicious circle, although always within the limits of the ecosystem, and not surpassing the recovery capabilities of the ecosystem functions [59]. 


\subsection{Structure of Values for the Technical Panel (FONATUR)}

FONATUR's structure of values is contained within a categorization in which objectives of an Economic type are preponderant. Notably, triggering regional development, as an expression of the mission with which FONATUR was created. This objective regards touristic development as the way to provide basic services, attract new investments, induce redistribution of wealth and foster population training according to the needs of this emerging industry.

It is worthwhile to underscore the objective of repositioning the Integrally Planned Center of Huatulco Bays through the diversification of touristic activities, because this institution seeks to promote tourism in contact with nature as the mainstay of these activities. This is a big change of vision for tourism in Mexico, as it is now sought to go beyond the traditionally dominant model of "sun and beach", looking instead towards more profitable high-quality alternatives that contribute to the conservation of environmental resources [60]. This intention seems apparent when it is stated, in the Environmental category, the will to stretch the useful life of resources that support touristic activity, as well as preserve and rationally use natural resources.

\subsection{Structure of Values for the Local Government Panel}

For the local government the concern seems to rest in the Environmental dimension of sustainability. It can be seen that the subjects of greater value are the environmental impact due to land use change and pollution, as well as the conservation of biodiversity. This suggests there is an acknowledgment of the pressures that threaten the current state of the environment and recognition of the value of environmental capital, an aspect which, if overlooked, will limit the success of any initiative to promote sustainability $[49,61]$. It also shows political will to contend with such problems, as proved by reforestation programs totally financed by the municipality, or the environmental consciousness campaigns financed in collaboration with FONATUR. It should be pointed out as well that it could also be a reflection of the political orientation of the current government which is a recognized factor that influences sustainability planning [31,62].

A remarkable point to notice is that interest in the environmental dimension transcends the economic, because ecotourism is regarded as a productive activity and other possibilities are conditioned to environmental conservation, at least in discourse. This preoccupation about the environment, coincides with the assertion, found in the 2007-2012 National Development Plan [63] and the 2004-2010 Sustainable Development State Plan for the state of Oaxaca [64], of a concern for the ecological sustainability of tourism development, which-it should be said-is deemed a national priority.

One characteristic of this hierarchy that could draw attention is the explicit absence of social criteria, since it is assumed that the government should act in favor of the social well-being. One possible explanation would be the rationale that improving the economy of the municipality will have, as a consequence, a generation of resources for more public works, for instance, which would indirectly benefit the community. This vision also concurs with that of the present state authorities, who identify tourism as the backbone of the state's economic development and as the means to benefit society in general [64]. 


\subsection{Structure of Values for the NGO}

Just like other NGOs in the world that have a relation with tourism, the Autonomous Group for Environmental Research organization (GAIA for its initials in Spanish), centers its values and activities on nature conservancy and environment protection [65]. Consequently, its economic and social objectives are influenced by a concern for the environment. In fact, this local NGO, as well as regional ones like CSE and Ecosolar, spurred by the rapid decline of tropical dry forest around Bahías de Huatulco, due to tourism development, intend to promote community well-being through work with the native communities to regenerate some of the smaller river basins in the region. This strategy is aligned with the general agreement that the integrity of ecosystems is a critical factor not just for sustainable tourism but for sustainable development in general [26,66,67]. Based on this principle, they have started to work with the communities to implement diversified development programs in which the forests would play a central role, but where complementary activities would offer an essential economic underpinning to assure its economic viability and guarantee sufficient opportunities to persuade people to stay and strengthen their confidence in community governance and management capabilities. The complementary activities envisioned in this strategy include ecotourism, a renewed emphasis on production of basic foods for local consumption, and commercial production of goods and services for local and specialized foreign markets [68]. Currently GAIA is developing the program Communitary System to Handle and Protect Biodiversity, and carries out programs of live fences, green fertilizers and reforestation. This NGO also collaborates with the communities promoting and commercializing their products. These initiatives can serve to overcome one of the main barriers for successful sustainable tourism indicated by Farsari et al. [69]: monoculture of tourism or the need to diversify economic activities.

\subsection{Structure of Values for the Academic Sector}

This structure reveals interests totally focused on the environmental dimension, a vision that could be explained by the intellectual tradition of the panel, constituted by ecologists, as Briassoullis [62] points out. Explicit in this hierarchy, is concern about the health and integrity of ecosystems, as determinants of the availability, in space and time, of environmental goods and services [70,71]. What also stands out is interest to prevent and control negative impacts on the environment caused by the expansion of tourism in the area.

\subsection{The Integrated Structure of Objectives and Their Associated Sustainability Indicators}

The result of the integration of values is the set of objectives summarized in Figure 1. Nine fundamental objectives characterize the vision of the interviewees regarding what should be important to FONATUR when considering future sustainable tourism development in the Copalita community.

Two of them belong to the environmental dimension, three to economic and social dimensions, respectively, and one to the political/institutional dimension. The overall fundamental objectives were particularized with a total of twenty three sub-objectives. This integration was made trying to ensure completeness and avoid redundancies in the structuring objectives as recommended by McDaniels and Trousdale [41]. 
Figure 1. Value Tree for monitoring advancement towards sustainability.

Environmental 1 - $\begin{aligned} & \begin{array}{l}\text { Conserve } \\ \text { goods and } \\ \text { services }\end{array} \\ & \text { Control deforestation } \\ & \text { Create consciousness among the population about } \\ & \text { environmental protection }\end{aligned}$

Prevent and control environmental impacts
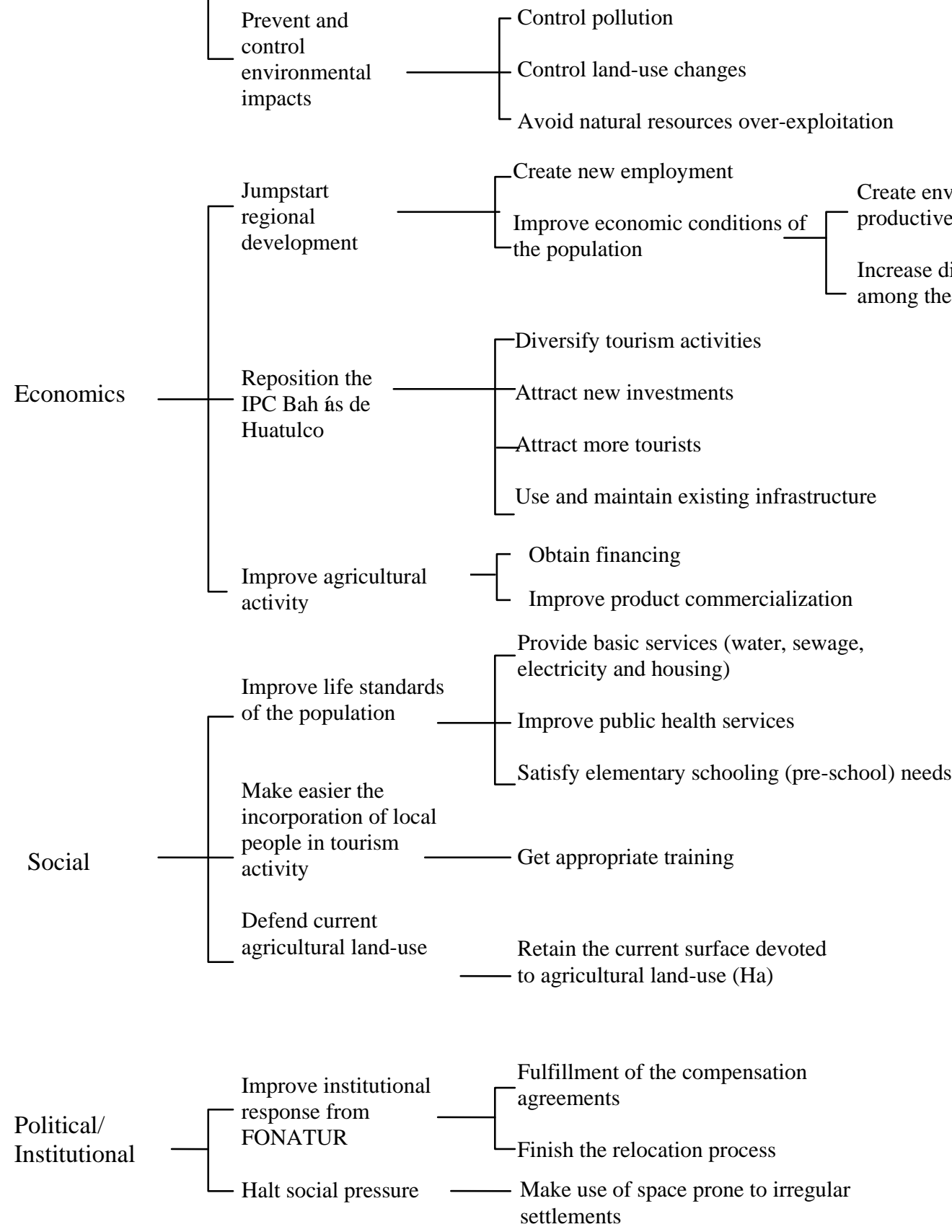

In accordance with Neto [33], the results show that multiple objectives necessarily matter for sustainability planning and monitoring. The application of Keeney's value-focused thinking has allowed an effective characterization of stakeholders' values. Comparison between the columns of Table 2 shows that the five sets of stakeholders share some objectives and also have some different concerns. That is not unexpected and it is helpful to make these differences explicit [72]. These 
objectives are useful in the negotiation process in multiple ways, for example serving as the basis to evaluate whether a future tourism development process moves towards sustainability.

The responses of the participants reveal that all of them value the conservation of ecosystem goods and services as a fundamental objective for the locality and for the region that comprises Bahías de Huatulco IPC, because they support life and human activities, including tourism. They also agree that, without the population's consciousness of the importance of protecting the environment, sustainability would be more difficult to achieve. Concern about environmental impact prevention and control is widely shared too. These three aspects are important since traditional "sun and beach" tourism in Mexico has been widely criticized for its environmental impact and inefficiency [73]. There is also an implicit recognition of the importance of jump starting regional development but with two different approximations: creating new jobs and, environmentally friendly productive projects. Furthermore, there is considerable agreement regarding the value of improving life standards of the population. The rest of the objectives are supported individually by different stakeholders, all of them being as valuable as those which show agreement for decision making [41]. The indicators derived from this set of objectives are presented in Table 3.

Table 3. Initial proposal of sustainability indicators for stakeholders' objectives.

\begin{tabular}{|c|c|c|}
\hline $\begin{array}{l}\text { Sustainability } \\
\text { Dimension }\end{array}$ & Main objective & Indicator \\
\hline \multirow{12}{*}{ Environmental } & \multirow{3}{*}{$\begin{array}{l}\text { Conserve ecosystem goods and } \\
\text { services }\end{array}$} & Population of rare, endangered or endemic species \\
\hline & & Visitors area/Reserve area \\
\hline & & Diversity of cultivated and natural species \\
\hline & \multirow{9}{*}{$\begin{array}{l}\text { Prevent and control environmental } \\
\text { impacts }\end{array}$} & $\%$ of land cover change \\
\hline & & Number of rooms built for lodging \\
\hline & & Waste amount/number of visitors ratio (yearly and peak averages) \\
\hline & & Recycled waste volume/Produced waste volume \\
\hline & & Treated water volume/Residual water volume \\
\hline & & Number of days air quality acceptable limits are exceeded \\
\hline & & River water quality \\
\hline & & River fishing resource production \\
\hline & & Spatial and temporal variations of the river course \\
\hline \multirow{13}{*}{ Economic } & \multirow{5}{*}{ Jumpstart regional development } & Weekly average $\%$ change in family income \\
\hline & & $\%$ change in family expenses \\
\hline & & Total number of employees in the touristic sector \\
\hline & & $\%$ of local population participating in tourism activities \\
\hline & & $\begin{array}{l}\text { Local community yearly income derived from tourism/ } \\
\text { Total income }\end{array}$ \\
\hline & \multirow{5}{*}{ Reposition the IPC Bahías de Huatulco } & Average visitor daily expenses on each touristic activity offered \\
\hline & & Average length of tourist stays \\
\hline & & Tourists' satisfaction level \\
\hline & & Number of land parcels sold by FONATUR to entrepreneurs \\
\hline & & Number of visitors over time and purpose of their visits \\
\hline & \multirow{3}{*}{ Improve agricultural activity } & Government Technical training programs \\
\hline & & Crop yield figures \\
\hline & & $\begin{array}{l}\text { Products of agricultural origin which are currently } \\
\text { commercialized }\end{array}$ \\
\hline
\end{tabular}


Table 3. Cont.

\begin{tabular}{|c|c|c|}
\hline \multirow{6}{*}{ Social } & \multirow{3}{*}{$\begin{array}{l}\text { Improve life standards of the } \\
\text { population }\end{array}$} & $\begin{array}{l}\text { Availability and access to services such as water, sewage, } \\
\text { transport, recreation, sports (\% allocated for tourism) }\end{array}$ \\
\hline & & $\begin{array}{l}\text { Availability and access to health services } \\
(\% \text { allocated for tourism) }\end{array}$ \\
\hline & & $\begin{array}{l}\text { Availability and access to pre-school installations } \\
(\% \text { allocated for tourism) }\end{array}$ \\
\hline & \multirow{2}{*}{$\begin{array}{l}\text { Make easier the incorporation of } \\
\text { local people in tourism activity }\end{array}$} & $\begin{array}{l}\text { Amount of investments earmarked for local personnel training } \\
\text { in tourism }\end{array}$ \\
\hline & & Number of certified local employees \\
\hline & Defend current agricultural land-use & $\%$ of change in area dedicated to agriculture \\
\hline \multirow{3}{*}{$\begin{array}{l}\text { Political/ } \\
\text { institutional }\end{array}$} & \multirow{3}{*}{$\begin{array}{l}\text { Improve Institutional response from } \\
\text { FONATUR }\end{array}$} & $\begin{array}{l}\text { New agreements between inhabitants and FONATUR } \\
\text { concerning compensation payment or relocation procedures. }\end{array}$ \\
\hline & & $\begin{array}{l}\text { Number of technical training programs for farmers } \\
\text { (production, commerce, tourism-related activities) }\end{array}$ \\
\hline & & $\begin{array}{l}\text { Cooperation programs to improve or create service } \\
\text { infrastructure }\end{array}$ \\
\hline
\end{tabular}

\section{Discussion}

The discussion is centered on how the proposed indicators suit both the decision context and the hierarchy of objectives, in order to clarify their pertinence. It is organized according to the sustainability dimensions used in the study. However, it should be acknowledged that there are inter-relationships among these dimensions and it will be apparent at times how the same indicator can be useful to monitor more than one objective.

\subsection{Environmental Dimension}

Farsari et al. [69] point out that one mistake made when including the environment within tourism policies has been to value it in a purely utilitarian way, which has led to ignoring the importance of conservation, or even further, the importance of nature preservation itself. It is because of this that the discussion of the environmental framework assumes, as a premise, that the environment should be accepted as the core component of sustainable development and as the key factor for the quality of life of the local population, instead of being regarded as a mere touristic resource.

From this point of view, it is important to underscore the concern shown by all interested parties for the conservation of the natural capital of the site. This is relevant if we consider that key environmental subjects in the area of study tend to become bottlenecks in making touristic developments sustainable [64]. In the case of Copalita - regarded as a space to develop touristic, recreational and educational activities based on nature - the destruction of vegetation as a result of poor planning is a restrictive factor to the development of such activities, because of its key role in shaping landscape beauty and as a habitat for different species; both aspects being widely recognized as ecosystem functions and touristic attractions [66,71,74]. Of particular importance is the riparian vegetation growing next to Copalita River, which confers distinctive traits and visual cues to the landscape of the 
site, offering exceptional opportunities for local recreation and touristic facilities like lookout points, scenic paths, cycle tracks, etc.

The additional role of vegetation cover as provider of environmental services, such as air and water purification and production, soil retention, erosion and landslide control, should not be forgotten, since in Copalita these are of paramount importance, specially at irregular settlements [73]. Drinking water depletion could very well be the factor to endanger the success of this touristic project, if it is realized that water demands must be met for all, the community, the visitors and the ecosystem that supports these activities. Consequently, through monitoring of vegetation changes, tourism management and its effectiveness might be evaluated regarding conservation of ecosystem goods and services as well as environmental impact [75].

Concern about conservation of NPA makes sense, because the density and intensive nature of their use at the site exerts more stress on the environmental and cultural assets, necessitating a control, and prioritizing, above all, long-term sustainability. In this case, load capacity seems to be the most likely candidate as a monitoring tool, as pointed out by Becker [67]. However, in the context of tourism, as Saveriades ([76], p. 148) indicates: "there is still neither a universally accepted definition nor a standard systematic procedure for assessing it". Moreover, the prevailing view in the literature is that although tourism's carrying capacity is a useful concept to help us understand sustainable tourism theoretically speaking, its practical application as a management tool is very limited [59,77]. Thus, a neat alternative can be the proportion of the reserve being visited (including scenic spaces and trails) relative to the total area, as an indicator of the conservation of goods and services.

Urban development and agriculture expansion are regarded as key pressures, potentially disrupting vegetal cover, resulting in deforestation. This is why emphasis is made on the need to control agricultural activity and to restructure land use at the touristic reserve and in the hotel zone. Wetlands protection is of particular importance in Copalita, preventing them from being drained or flooded as a consequence of excessive demand of lands, in the urge to build more lodging spaces, a practice that would breach the schemes proposed in master plans, not to mention restrictions imposed by the law regarding land use categories, occupation coefficients, etc. Monitoring land cover changes in this context, the extension of agricultural lands, and the number of rooms built, look like proficient indicators of the evolution of these phenomena. The same can be said of wetland area change [75].

Yet another aspect of the environment that concerns the stakeholders is pollution impact, together with over-exploitation of natural resources, being worthy subjects for concern. Pertaining pollution, solid waste, residual waters and clean air, are of the utmost importance, not only because of their visual impact on landscape, but for their effect on the health of the community and visitors alike. Additionally, if the site has a poor reputation for being untidy and littered, visitors will usually avoid it. Although the reaction to waste or to polluted air varies from one individual to another, and is usually related to comparative conditions in the country of origin, the perception of a clean place can be a factor in the decision to return or recommend it to others. Here, the amount of solid waste with respect to the number of visitors (yearly and peak season averages) and the number of days exceeding air-quality deterioration limits seem likely and useful indicators to monitor the evolution of these pressures over the environment as a result of tourism management.

Nevertheless, thinking in terms of the ecosystem's ability to process and assimilate contaminants, as well as recycling resources, biodiversity, the proportion of treated versus the total volume of residual 
water, and recycled waste volume versus produced waste volume, turn out to be the most significant from a perspective of environmental sustainabilty [78]. This should alert FONATUR about established construction standards, in order to have service providers separate sewage from rain water from the moment of building their facilities. Currently, these waters are channeled indiscriminately to sumps or treatment plants since - to this date - the infrastructure is not able to cope with the volume of waste water produced. Furthermore, if the government is to be consistent with its disposition to support tourism as a productive and environmentally friendly activity, it will have to act accordingly, setting up efficient waste collection and final waste disposal services, thus complying with the requirements for environment protection. The community would not be excluded from their individual responsibilities of separating waste and avoiding littering, to which end it will be necessary to promote a culture of proper waste disposal. At this point, the sole presence of waste could act as an indicator of the effectiveness of the actions taken by the local government [45].

Regarding the extraction of materials for construction, the point where local attention is focused is rock extraction from the Copalita River. It is fundamental to control the intensive exploitation of this resource, as it can have impacts such as changes in the river course and habitat suppression. The importance of taking care of this river should be stressed in the face of intervention from the touristic industry, since it constitutes a food resource for the community. Relevant monitoring in this aspect should be fisheries resource production from the river, the quality of its water and its spatial and temporal variations, which concurs with the opinion of authors such as Li [66] and Shirakaya et al. [78] regarding the incorporation of the concept of naturalness in sustainable tourism management.

\subsection{Economic Dimension}

Considering the economic objectives the stakeholders expect from tourism, the generation of new opportunities for local development, job creation as a way to improve the standard of living of the community, training - to allow the local population to take part in tourism economic activities-are key items in the revitalization and strengthening of communities, all of them advocated by sustainable tourism [57]. Jobs created by tourism can be a factor to curb migration from rural areas. Local population can increase their influence on tourism development and improve their employment and income chances through professional training or developing skills to start up businesses. It should not be forgotten that for politicians and opinion leaders alike, job opportunities are a key factor influencing the decision to support or invest in tourism, which in turn can determine its economic sustainability. Consequently, the indicators needed are those that can provide information on the impact of this activity on local control of tourism related businesses, on the employment of the local population, on families' income, on the revenues that remain in the community and their distribution, etc. [79]. However, it should not be overlooked that these benefits can be affected by a raise in the cost of living as a consequence of tourism, which will require indicators that allow estimations of net economic benefits to the community. In this sense, the World Tourism Organization [45] recommends base indicators as the weekly average percent increase or decrease in household income or the percent increase or decrease of household expenses (food, transportation, recreation, etc.).

Seeing the interest of FONATUR in increasing the economic potential of the Huatulco IPC, it is necessary to have ready access to basic information about tourism industry economic results and on the 
degree of satisfaction of the touristic experience [36]. Starting from the objective of diversifying tourism activities, it could be thought that monitoring visitors' expenses per day on each of the activities offered, or the length of their stays may serve to measure the impact of the touristic strategy. The tourist's level of satisfaction, expressed through a questionnaire, can also be used to evaluate this impact. Theoretically, a larger number of activities will result in visitors lengthening their stays in order to experience them all. Furthermore, it has also been stated that tourists taking advantage of a variety of experiences at a destination will usually find it more gratifying [74]. This is relevant, since tourists' satisfaction is central to their return and recommendation of the site to others.

Concerning the interest in being able to attract new investments, the number of land parcels sold could work as an indicator of the evolution towards this objective. In fact, FONATUR already uses it in its planning processes. As to the objective of attracting more tourists, their numbers over time and the purpose of their visits are the most likely indicators [45].

The values expressed in the economic dimension inform over other aspect linked to tourism development within the context of sustainability: the local role of agriculture. It is the preponderant economic activity for the community - the base of their sustenance-whose mainstays are corn growing and papaya production. As it happens, the community is interested in increasing production as an alternative to improve family income. This matter should not be overlooked if the intention is really to set off development in the locality, as stated by FONATUR, since an economic structure which depends on a single activity, like tourism, is a serious threat to the economic sustainability of the region [80]; because dependence on tourism fosters a dependence on the distribution channels and the people who make this activity work. Farsari et al. [69] have remarked that almost all inhabitants in a touristic area are involved in tourism through the same actions, like the rent of rooms and vehicles, establishment of restaurants, souvenir shops, etc., resulting in a high competition for the limited job resources, instead of having complementary and support activities, putting social sustainability at risk.

In the face of such a situation, several authors support the vision of diversifying the economies of touristic destinations. Agriculture - which is related to tourism as a consumer of its products - together with other traditional activities, is proposed as an option to strengthen and stabilize the economy [80,81]. It will then be necessary, to improve the conditions of this activity at the locality, by promoting crop rotation, improving agro-ecosystem's resilience and breaking the dependence on revenues obtained from a single product, which can be adversely affected by market changes. Resilience estimates can be made from inputs such as cultivated species diversity - a contributing factor of resilience — or through outputs that are affected by resilience changes, such as crop yield. The convenience of using these indicators has been proven by Conway et al. [82] in the analysis of agro-ecosystems and also by Gutierrez-Espeleta [83] in the estimation of the Approximate Sustainability Index.

Tourism development should also promote that hotels and local stores consume local agricultural products as well as value-added products derived from them. Regarding this, government initiatives directed towards technical training for farmers and opening of product commercialization channels as well as the number of products of agricultural origin which are currently commercialized can be the indicators of the contribution made by tourism to the strengthening of communities, as prescribed by UNEP [57]. 


\subsection{Social Dimension}

Turning now to the social environment, tourism's influence on the objective of improving the population's standard of living could be appraised in the following ways. Installations and services developed primarily for tourists can benefit inhabitants; services which would hardly be installed otherwise. These benefits include the creation or upgrade of water distribution infrastructure or sewage disposal, creation or upgrade of transportation or health services, new recreational or sports activities and other public spaces. On the other hand, the construction of these types of infrastructure for the benefit of society as a whole is a way to share with tourism the responsibility for the intensive use of natural resources like water and energy, greater waste and residual water generation, or for the displacement of other productive activities. The number, type and capacity of services available to the community, as well as the population's percentage that has access to them can be the indicators of improvement in the standard of living, a point of concern for the inhabitants of Copalita [45]. It should be stressed that, while the direct responsibility of providing infrastructure and services for the community lies in the local government, it is also true that a synergy between FONATUR and local government can step up the impact in this area. Hence, the coordination of these two actors through joint programs can be a political/institutional indicator of progress towards sustainable tourism.

On the other hand, it is worth mentioning here that the conservation of Natural Protected Areas (NPA) is a subject of interest both to the community and to FONATUR. Specifically in the latter case, because the degree of conservation of the environmental wealth of these areas opens up the possibility, not only for developing quality touristic projects in contact with nature that, at the same time, diversify the offer and promote the participation of new investments, but because they are opportunities for training local personnel and incorporating it in tourism activities. In this respect, the amount of investment earmarked for personnel training in tourism and the number of certified employees could serve as an indicator of the degree of success for this objective.

\subsection{Political/Institutional Dimension}

The interest of the inhabitants of Copalita in agricultural lands is specifically the conservation of the area currently devoted to this activity, independent of other land uses that might arise over time. This demand is related to agriculture as a basic economic activity - a point already discussed — and the delicate subject of land ownership. Technically, FONATUR is the owner of the site of study and agricultural lands are subject to the fund's priorities, but are lent to farmers as long as they are not needed for other purposes. From the point of view of sustainable tourism, one way to reconcile diverging interests would be to reach an agreement with farmers, incorporate this economic activity into tourism, providing environmental goods and services [69]. The idea would be that farmers, in exchange for agricultural lands, agree to produce organic goods, to make an efficient use of water and prevent erosion and soil depletion. Under these assumptions, a sort of rural tourism could be offered, where agricultural activities and products alike could be attractions for visitors, delivering profits to all. Once again, the number of cooperation programs could be an indicator of advancement. Also, the number of farmers committed to these initiatives and the percentage of change in area dedicated to 
agriculture could be a measure of the participation of the community in touristic activities and of the respect for local cultural practices [78].

\section{Conclusions}

Tourism management involves aspects from environmental, social, health, educational, economic and political/institutional dimensions. The case study of Copalita shows that all these aspects were brought to light in a clear and logical manner by employing value-focused thinking. It also shows that objectives determine the identification of sustainability indicators that respond to local aspirations and conditions.

It has been postulated that it is a paradox to strive to develop indicators for sustainable tourism when a unique definition of the concept is not available. Nevertheless, when the starting point is a flexible and dynamic vision of sustainability, the process of identifying and structuring objectives to be pursued helps provide the concept with an explicit local identity, because "frequently, people have a clear idea of what sustainability is from their own perspective and under their own terms, without the expert vision of the expert" as Bell and Morse [80,84] point out. Moreover, if the concept of sustainable tourism is to be understood and accepted by the general public, it must be relevant to them. In this sense, the approach followed by this research was an attempt to launch the planning process of the Integrally Planned Centers (IPC) with the participation of diverse involved parties, and its results have been satisfactory. From a practical perspective, this attempt implied incorporating the opinions of different groups in identifying objectives. This ensures that values from a wide range of stakeholders are reflected in the planning process, providing a constructive procedure for individuals — with potentially contradicting points of view - to participate in the solution of the problems that concern and affect them.

When the incorporation of a community to touristic activities is sought within the context of local sustainability, the process of eliciting information about the objectives to be monitored establishes a base for communication, dialog and negotiation of the parties involved. This is of great importance for FONATUR, since the sustainability of a touristic destination can be interrupted if adverse reactions from participating groups are significant and ever increasing. As asserted by Faulkner and Tideswell ([85], p.6) "reciprocal reactions associated with a community influence the progress of the different stages, reducing the attractiveness of the area for tourists, thus limiting its viability as a touristic destination".

While there is evidence that local sustainability indicators do not significantly influence decision making, this is not necessarily the fatal verdict it seems to be. Indicators have a clear and well defined set of benefits: they help organizations to assimilate and better understand the visions of interested parties about sustainability; they contribute to the governance process [53] and, when the local context is considered, that help guide and shape decisions on public policies associated, for example, with tourism. What is most important to understand from the academic and professional perspective, is that indicators work as part of the governance process, not like exogenous factors that can be launched, magically turning decision making into an objective and scientific practice. Creating successful indicators, depends a lot more on finding a way to integrate them into the process, and a lot less on building, designing or tinkering with a specific set of indicators. 


\section{Acknowledgements}

The authors express their gratitude to Gerardo Juárez for comments and suggestions regarding this manuscript. Additionally, for very helpful review comments we thank three anonymous referees.

\section{References and Notes}

1. Wall, G. Is ecotourism sustainable? Environ. Manag. 1997, 21, 483-491.

2. WTTC. Welcome to WTTC. Available on line: http://www.wttc.org/ (accessed on 1 July 2010).

3. Fondo Nacional de Fomento al Turismo (FONATUR). México se consolida como potencia turística: John McCarthy en la inauguración de la BMIT. BOLETIN 2005, 20, 2-5.

4. Presidencia de la República. Segundo Informe de Gobierno, Turismo. Gobierno de los Estados Unidos Mexicanos, 1 de Septiembre, 2008. Available online: http://www.cefp.gob.mx/intr/ boletin/boletin2008/bolcefp1272008.pdf (accessed on 3 May 2010).

5. Budeanu, A. Impacts and responsibilities for sustainable tourism: A tour operator's perspective. J. Clean. Prod. 2005, 13, 89-97.

6. Instituto Nacional de Ecología. Medio Ambiente y Turismo; SEMARNAP: Ciudad de México, México, 2000; pp. 19-27.

7. Blancas, F.J.; González, M.; Lozano-Oyola, M; Pérez, F. The assessment of sustainable tourism: Application to Spanish coastal destinations. Ecol. Indic. 2010, 10, 484-492.

8. Tourism: the Year 2000 and Beyond Qualitative Aspects; World Tourism Organization: Madrid, Spain, 1993.

9. Coccossis, H. Tourism and Sustainability: Perspectives and Implications. In Sustainable Tourism? European Experiences; Priestley, G., Edwards, J.A., Coccossis, H., Eds.; CAB International: London, UK, 1996.

10. Evanthie, M.; Hills, J.; Amat, J.P. Developing sustainable tourism, using a multicriteria analysis on renewable energy in Mediterranean Islands. Energy Sustain. Dev. 2009, 13, 129-136.

11. Liu, Z. Sustainable tourism development: A critique. J. Sustain. Tour. 2003, 11, 459-475.

12. Castellani, V.; Sala, S. Sustainable performance index for tourism policy development. Tour. Manag. 2009, 31, 871-880.

13. What Tourism Managers Need to Know: A Practical Guide to the Development and Use of Indicators of Sustainable Tourism; World Tourism Organization: Madrid, Spain, 1996.

14. Bell, S.; Morse, S. Breaking through the glass ceiling: who really cares about sustainability indicators? Local Environ. 2001, 6, 291-309.

15. Core Set of Indicators for Environmental Performance Reviews. A Synthesis Report by the Group on the State of the Environment; Organization for Economic Co-operation and Development: Paris, France, 1993.

16. Prescott-Allen, R. Wellbeing of Nations: A Country by-Country Index of Quality of Life and the Environment; Island Press: Washington, DC, USA, 2001.

17. Bossel, H. Assessing viability and sustainability: A systems-based approach for deriving comprehensive indicator sets. Conserv. Ecol. 2001, 5, 12-19. 
18. Reed, M.S.; Fraser, E.; Dougill, A. An adaptive learning process for developing and applying sustainability indicators with local communities. Ecol. Econ. 2006, 59, 406-418.

19. Checkland, P. Systems Thinking, Systems Practice; John Wiley: Chichester, UK, 1981.

20. The Natural Step. Available online: http://www.naturalstep.org/ (accessed on 25 July 2010).

21. Keeney, R.L. Value-Focused Thinking: A Path to Creative Decision-Making; Harvard University Press: Cambridge, MA, USA, 1992; pp. 3-28.

22 Stagl, S. Multicriteria evaluation and public participation: the case of UK energy policy. Land Use Policy 2006, 23, 95-107.

23. Twining-Ward, L.; Butler, R. Implementing sustainable tourism development on a small island: Development and use of sustainable tourism development indicators in Samoa. J. Sust. Tour. 2002, 10, 363-387.

24. Reed, M.S.; Doughill, A.J. Facilitating grass-roots sustainable development through sustainability indicators: A Kahalahari case study. In Proceedings of the Frontiers 2: European Applications in Ecological Economics Conference, Tenerife, Spain, 12-15 February 2003; pp. 1-19.

25. Rydin, Y.; Holman, N.; Wolff, E. Local sustainability indicators. Local Environ. 2003, 8, 581-589.

26. Farsari, Y.; Prastacos, P. Sustainable tourism indicators for Mediterranean established destinations. Tour. Today 2001, 1, 103-121.

27. Commission on Sustainable Development. Available online: http://www.un.org/esa/sustdev/ indisd/indisd-mg2001.pdf (accessed on 15 February 2003).

28. Keeney, R. Using values in operations research. Oper. Res. 1994, 42, 793-813.

29. Keeney, R.L. Structuring objectives for problems of public interest. Oper. Res. 1998, 36, 396-405.

30. Raiffa, H. The Art and Science of Negotiation; Harvard University Press: Cambridge, MA, USA, 1982; pp. 50-61.

31. Yafee, S.L.; Philips, A.F.; Frentz, I.C.; Hardy, P.W.; Maleki, S.M.; Thorpe, B.E. Ecosystem Management in the United States: An Assessment of a Current Experience; Island Press: Washington, DC, USA, 1996; p. 456.

32. Secretaría de Turismo. Programa Nacional de Turismo 2001-2006; SECTUR: Ciudad de México, México, 2001; pp. 60-65.

33. Neto, F. A new approach to sustainable tourism development: moving beyond environmental protection. Nat. Resour. Forum 2003, 27, 212.

34. Milne, S.; Ateljevic, I. Tourism, economic development and the global local nexus: Theory embracing complexity. Tour. Geogr. 2001, 3, 369-393.

35. Godde, P.M.; Price, M.F.; Zimmermann, F.M. Tourism and development in mountain regions: Moving forward into New Millenium. In Tourism and Development in Mountain Regions; Godde, P., Price, M.F., Zimmermann, F.M., Eds.; CAB International: Oxon, UK, 2000; pp. 1-26.

36. Ko, T.G. Development of a tourism sustainability assessment procedure: A conceptual approach. Tour. Manag. 2005, 16, 431-445.

37. Tortajadas, C.; Biswas, A.K. Environmental management of water resources in Mexico. Water Int. 2000, 25, 20-31.

38. Keeney, R.L. Creativity in decision making with value-focused thinking. Sloan Manag. Rev. 1994, Summer, 33-41. 
39. Keeney, R.L.; McDaniels, T.L. Value-focused thinking. About strategic decisions at BC hydro. Interface 1992, 22, 94-109.

40. Kajanus, M.; Kangas, J.; Kurtill, M. The use of value focused thinking and the A'WOT hybrid method in tourism management. Tour. Manag. 2004, 25, 499-506.

41. McDaniels, T.; Trousdale, W. Value-focused Thinking in a difficult context: planning tourism for Guimaras, Phillipines. Interface 1999, 24, 58-70.

42. Gregory, R.; Keeney, R.L. Creating policy alternatives using stakeholder values. Manag. Sci. 1994, 40, 135-148.

43. Gimate, S.A. Ordenamiento territorial basado en la identificación de áreas ecológicamente sensibles con criterios múltiples: Estudio de caso ribera del Río Copalita, Oaxaca; Bachelor Thesis; Universidad Autónoma Metropolitana Xochimilco: Ciudad de México, México, 2004; pp. 10-14.

44. Instituto Nacional de Ecología. Norma Oficial Mexicana NOM-05-ECOL-2001 para la protección ambiental: Especies nativas de México de flora y fauna silvestres. Available online: http://www.ine.gob.mx/ueajei/norma59a.html (accessed on 22 October 2009).

45. Indicators of Sustainable Development for Tourism Destination. A guide Book; World Tourism Organization: Madrid, Spain, 2004; p. 500.

46. Jennings, M.M. Stakeholder Theory: Letting Anyone Who's Interested Run The Business-No Investments Required. Available online: http://www.stthom.edu.cbes/conferences/marianne_ jennings.html (accessed on 5 September 2009).

47. Smith, L.G. Impact Assessment and sustainable Resource Management; Longman Scientific and Technical: Harlow, UK, 1993.

48. Costanza, R. Frontiers in Ecological Economics: Transdisciplinary Essays by Robert Costanza; Edward Elgar: Cheltenham, UK, 1997.

49. Chávez, C.M.M. Planning for Sustainability: A Transdisciplinary Approach Applied to Water Resources in Mexico; PhD Thesis; University of Liverpool: Liverpool, UK, 2004; p. 260.

50. Meppen, T.; Gill, R. Planning for sustainability as a learning concept. Ecol. Econ. 1998, 26, 121-137.

51. Keller, L.R.; Ho, J.L. Decision Problem Structuring: Generating Options. IEEE Trans. Syst. Man Cyber. 1998, 18, 715-737.

52. Arksey, H.; Knight, P. Interviewing for Social Scientists; SAGE: London, UK, 1999; pp. 26-38.

53. Alliance for Nonprofit Management. What Do I Need to Know before I Start the Planning Process? Available online: http://allianceonline.org/FAQ/strategic_planning/what_do_I_need_to _know.faq (accessed on 17 January 2010).

54. Blaxter, L.; Hughes, C.; Tight, M. How to Research, 2nd ed.; Open University Press: Buckingham, UK, 1998; pp. 37-45.

55. Keeney, R.L.; Raiffa, H. Decisions with Multiple Objectives: Preferences and Value Tradeoffs; Cambridge University Press: Cambridge, UK, 1993; pp. 41-49.

56. von Winterfieldt, D. Structuring decision problems for decision analysis. Acta Psychol. 1980, 45, 71-93.

57. Waterman, H.; Tillen, D.; Dickson, R.; de Koning, K. Action research: A systematic review and guidance for assessment. Health Technol. Assess. 2001, 5, 11-16, 29-41. 
58. Allen, P.; Sachs, C. The social side of sustainability: Class, gender and race. Sci. Cult. 1991, 2, 569-590.

59. White V.; McCrum G.; Blackstock, H.L.; Scott, A. Indicators and Sustainable Tourism: Literature Review; The Macaulay Institute: Aberdeen, UK, 2006; p. 27.

60. Secretaría de Turismo. Programa Sectorial de Turismo 2007-2012; SECTUR: Ciudad de México, México, 2010; pp. 10-12.

61. Aguilera-Klint, F.; Pérez-Moriana, E.; Sánchez-García J. The social construction of scarcity. The case of water in Tenerife (Canary Islands). Ecol. Econ. 2000, 34, 233-245.

62. Briassoullis, H. Theoretical Orientations of Environmental Planning: An Inquiry into Alternative Approaches. Environ. Manag. 1989, 13, 381-392.

63. Presidencia de la República. Plan Nacional de Desarrollo 2007-2012. Available online: http://pnd.presidencia.gob.mx (accessed on 11 August 2010).

64. Gobierno del Estado de Oaxaca. Plan Estatal de Desarrollo Sustentable 2004-2010. Available online: http://transparencia.finanzasoaxaca.gob.mx/pdf/marco/Plan_Estatal_de_Desarrollo_ Sustentable_2004-2010.pdf (accessed on 13 August 2010).

65. NGOs in Tourism and Conservation Conference October-November 2002. Available online: http://www.planeta.com/ecotravel/tourism_conservation.html (accessed on 11 August 2010).

66. Li, W. Environmental management indicators for ecotourism in China's nature reserves: A case study in Tianmushan Nature Reserve. Tour. Manag. 2004, 25, 559-564.

67. Becker, J. Measuring Progress Towards Sustainable Development: An Ecological Framework for Selecting Indicators. Local Environ. 2005, 10, 87-101.

68. Barkin, D.; Pailles, C. NGO-Community Collaboration for Ecoturism: A strategy for Sustainable Regional Development in Oaxaca. Available online: http://www.planeta.com/planeta/99/ 0499huatulco.html (accessed on 6 August 2010).

69. Farsari, Y.; Butler, R.; Prastacos, P. Sustainable tourism policy for Mediterranean destinations: Issues and interrelationships. Int. J. Tour. Policy 2007, 1, 58-78.

70. Chapin, F.S., III; Matson, P.; Mooney, H. Principles of Terrestrial Ecosystem Ecology; Springer Science+Business Media: New York, NY, USA, 2002.

71. De Groot, R.S.; Wilson, M.A.; Boumans, R.M.J. A typology of the classification, description and valuation of ecosystem functions, goods and services. Ecol. Econ. 2002, 41, 393-408.

72. Sebenius, J.K. Negotiation analysis: a characterization and review. Manag. Sci. 1992, 38,18-38.

73. Borja, C.J.; Gómez, U.R. Condicionantes del turismo sustentable en el caribe mexicano. Études caribéennes 2009, 13, 1-10.

74. Reynolds, P.C.; Braithwait, D. Towards a conceptual framework for wildlife tourism. Tour. Manag. 2001, 22, 31-42.

75. Kammerbauer, J.; Cordoba, B.; Escolán, R.; Flores, S.; Ramírez, V.; Zeledón, J. Identification of development indicators in tropical mountainous regions and some implications for natural resource policy designs: an integrated community case study. Ecol. Econ. 2001, 36, 45-60.

76. Saveriades, A. Establishing the social tourism carrying capacity for the tourist resorts of the east coast of the Republic of Cyprus. Tour. Manag. 2000, 21, 147-156.

77. Lindberg, K.; McCool, S.F.; Stankey, G. Rethinking Carrying Capacity. Ann. Tour. Res. 1997, 24, 461-465. 
78. Sirakaya, E.; Jamal, T.B.; Choi, S. Developing Indicators for destination Sustainability. In The Encyclopedia of Ecoturism; Weber, D.B., Ed.; CAB International: Oxon, UK, 2001; pp. 411-432.

79. Burns, P.M.; Montalvillo, S.M. Local perceptions of tourism planning: The case of Cuéllar, Spain. Tour. Manag. 2003, 24, 331-339.

80. Williams, M.T. An expansion of the tourist site cycle model: the case of Minorca, Spain. J. Tour. Studies 1993, 4, 24-32.

81. Buhalis, D. Tourism on the Greek islands: Issues of peripherality, competitiveness and development. Int. J. Tour. Res. 1999, 1, 341-358.

82. Conway, G.R.; McCracken, A.J. Rapid rural appraisal and agroecosystem analysis. In Agroecology and Small Farms Development. Boca Ratón, Ann Arbor, Boston, USA; Altieri, M.A., Hecht, B.S., Eds; CRC Press: Boston, MA, USA, 2000; pp. 221-234.

83. Gutiérrez-Espeleta, E.E. The approximated sustainability index: A tool for evaluating sustainable performance. In Accounting for Change; MacGillivray, A., Ed.; NEF: London, UK, 1995, pp. $42-47$.

84. Bell, S.; Morse, S. Sustainability Indicators: Measuring the Immeasurable; Earthscan: London, UK, 1999; p. 80.

85. Faulkner, B.; Tideswell, C. A framework for monitoring community impacts of tourism. J. Sustain. Tour. 1997, 5, 3-28.

(C) 2010 by the authors; licensee MDPI, Basel, Switzerland. This article is an open access article distributed under the terms and conditions of the Creative Commons Attribution license (http://creativecommons.org/licenses/by/3.0/). 